\title{
Assessment of ecologically relevant hydrological change in China due to water use and reservoirs
}

\author{
J. Zhang and P. Döll \\ Institute of Physical Geography, University of Frankfurt, Germany \\ Received: 14 December 2007 - Revised: 7 March 2008 - Accepted: 28 May 2008 - Published: 20 June 2008
}

\begin{abstract}
As China's economy booms, increasing water use has significantly affected hydro-geomorphic processes and thus the ecology of surface waters. A large variety of hydrological changes arising from human activities such as reservoir construction and management, water abstraction, water diversion and agricultural land expansion have been sustained throughout China. Using the global scale hydrological and water use model WaterGAP, natural and anthropogenically altered flow conditions are calculated, taking into account flow alterations due to human water consumption and 580 large reservoirs. The impacts resulting from water consumption and reservoirs have been analyzed separately. A modified "Indicators of Hydrologic Alteration" approach is used to describe the human pressures on aquatic ecosystems due to anthropogenic alterations in river flow regimes. The changes in long-term average river discharge, average monthly mean discharge and coefficients of variation of monthly river discharges under natural and impacted conditions are compared and analyzed. The indicators show very significant alterations of natural river flow regimes in a large part of northern China and only minor alterations in most of southern China. The detected large alterations in long-term average river discharge, the seasonality of flows and the inter-annual variability in the northern half of China are very likely to have caused significant ecological impacts.
\end{abstract}

\section{Introduction}

In March 1994, the government of China announced its plans for sustainable development in a White Paper entitled "China's Strategy for Population, Environment and Development in the 21st Century" (Government of China, 1994).

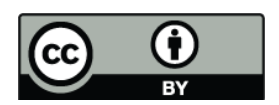

Correspondence to: J. Zhang

(jizhang@stud.uni-frankfurt.de)
The paper indicates that it is urgent to protect the natural functions of water resources in relation to hydrology, biology and chemistry, and adjust human activities to within the limits of nature and implement the sustainable development impact assessment system in the decision-making for water resource management (Chapter 14). To fulfill these goals, an assessment of hydrological changes due to human impacts that integrates ecological aspects is needed for all of China.

Hydrologic regimes play a major role in determining the biotic composition, structure, function and diversity within river ecosystems (Richter et al., 1996; Arthington and Pusey, 1993). In recent years, the importance of flow variability for river ecosystems has been well documented in many studies (e.g. Poff and Ward, 1989; Poff et al., 1997; Richter et al., 1996, 1997; Puckridge et al., 1998; Clausen and Biggs, 2000). A "natural flow paradigm" is suggested by accumulated research on the relationship between hydrological variability and river ecosystem, stating that "the full range of natural intra- and interannual variability of hydrological regimes, and associated characteristics of flow magnitude, frequency, duration, timing and rate of change, are critical in sustaining the full native biodiversity and integrity of aquatic ecosystems" (Richter et al., 1997; Poff et al., 1997). Introducing natural flow paradigm into hydro-ecological system management requires a means to analyze both natural and altered hydrological regimes (Black et al., 2005). The Indicators of Hydrologic Alteration (IHA) approach of Richter et al. (1996) has been widely adopted because of its comprehensive ability to characterize ecologically relevant hydrological changes. In this method, two sets of flow time series representing natural and altered conditions at the same site are compared using 32 indicators spanning the five characteristics mentioned above.

In this study, a first assessment of ecologically relevant hydrological regime alteration due to human water use and reservoirs is performed for China. Due to the lack of consistent and reliable observed data, both natural and

Published by Copernicus Publications on behalf of the European Geosciences Union. 


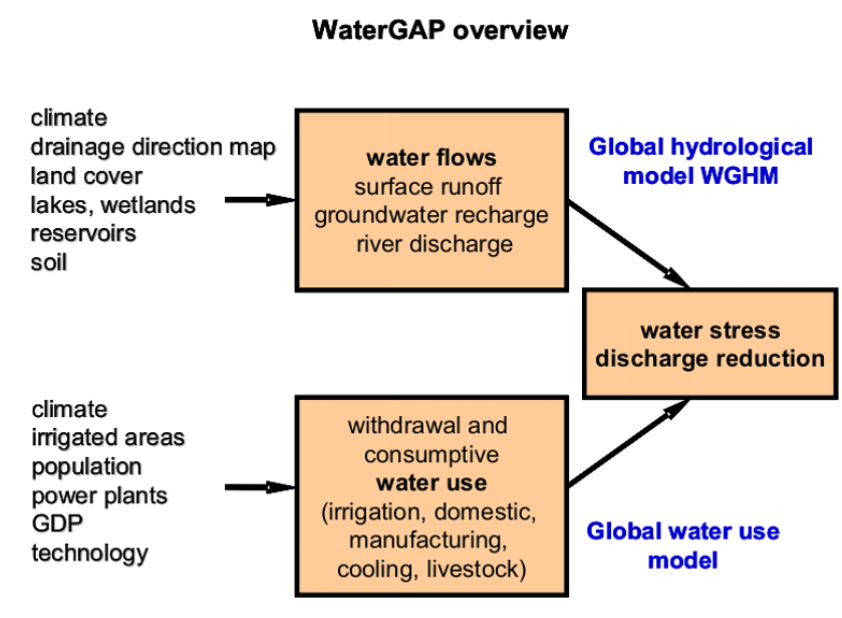

Fig. 1. An overview of WaterGAP.

anthropogenically altered flows are simulated by the WaterGAP Global Hydrological and Water Use Model (Alcamo et al., 2003; Döll et al., 2003). In the second part, the alteration of the hydrological regime is described by both changes in the long-term average flows and by a modified IHA methodology, where the 12 monthly long-term average river discharges and the 12 coefficients of variation of monthly river discharge in each 0.5 degree grid cell are compared.

\section{Methods}

The estimation of the impacts of human activities on river flow regimes in China is accomplished by comparing anthropogenically altered flows (AAF) with the natural (or reference) flows (NAT). The latter has been computed by assuming, in the WaterGAP model runs, that no human water consumption occurs and that there are no reservoirs. In order to analyze the impacts of water consumption and reservoirs separately, WaterGAP was also run by including consumption only but no reservoirs (USE) and by including only reservoirs but no human water consumption (RES). The four discharge data sets are calculated using the global hydrological and water use model WaterGAP for the period of 1961-1990 at selected gauging stations and per 0.5 degree grid cell in all of China.

The WaterGAP model (Water-Global Analysis and Prognosis) was developed to assess and predict water availability and water use worldwide. It combines a global hydrological model and several water use models, which take industrial and domestic water use as well as water withdrawals for irrigation and livestock into account (Fig. 1). WaterGAP operates with an internal time step of one day and a spatial resolution of $0.5^{\circ}$ latitude by $0.5^{\circ}$ longitude. The calculations are based on spatially distributed physiographic characteristics and on time series of climatic data (see Döll et al., 2003; for detail). The "Global Lakes and Wetlands Database" (GLWD) is integrated to supply information on large lakes and reservoirs, smaller surface water bodies and wetlands on a global scale (Lehner and Döll, 2004). For this study, 522 georeferenced reservoirs have been added to GLWD for China, so that the impact of a total of 580 reservoirs on the alteration of river flow regimes in China was assessed (see Fig. 2). The model version used in this study is WaterGAP 2.1f version which is tuned against long-term average river discharge at 1235 stations (19 of them are in China) around the world (Hunger and Döll, 2007).

The method used to assess impacts on aquatic system resulting by anthropogenically altered river flow regimes in China is based on the "Indicators of Hydrologic Alteration (IHA)" approach (Richter et al., 1997; Black et al., 2005). Only indicators based on monthly (and not daily) flows are taken into account in this study due to the high uncertainty of daily river discharges computed by WaterGAP which is mainly due to the fact that only monthly climate data are available as input. Twelve 12 monthly means of river discharge for the period 1961-1990 and twelve12 coefficients of variation of monthly discharge for the same period are computed for each grid cell both under natural and anthropogenically altered conditions. Then, two summary indicators representing the average absolute changes in monthly means and in coefficients of variation are obtained as:

$M N_{\mathrm{diff}}=\frac{1}{12} \times \sum_{i=1}^{12}\left(\frac{\left|M N_{\mathrm{AAFi}}-M N_{\mathrm{NATi}}\right|}{M N_{\mathrm{NATi}}}\right) \times 100 \%$

$C V_{\mathrm{diff}}=\frac{1}{12} \times \sum_{i=1}^{12}\left(\frac{\left|C V_{\mathrm{AAFi}}-C V_{\mathrm{NATi}}\right|}{C V_{\mathrm{NATi}}}\right) \times 100 \%$

where $M N_{\text {diff }}$ is the average absolute change in monthly mean river discharge, $M N_{\mathrm{AAFi}}$ is the long-term monthly mean in month $i$ under anthropogenically altered condition, $M N_{\mathrm{NATi}}$ is the long-term monthly mean river discharge in month $i$ under natural condition, $C V_{\text {diff }}$ is the average absolute change of coefficients of variation of monthly river discharge, $C V_{\mathrm{AAFi}}$ is the coefficient of variation in month $i$ under anthropogenically altered condition and $C V_{\mathrm{NATi}}$ is the coefficient of variation in month $i$ under natural condition.

\section{Results}

In Fig. 3, the calculated long-term average (1961-1990) annual river discharges for the four different flow conditions (natural and three different anthropogenically altered flow conditions) are shown for all 0.5 degree grid cells in China. Comparison between AAF and NAT (see Fig. 3a) shows that in many grid cells in the Haihe, upper Yellow River basins and north-western China, discharge under AAF conditions is reduced by more that $50 \%$ as compared to natural flow conditions. In the central Songhuajiang, lower Yellow River and northeastern part of Yangtze River basin, natural flow is reduced by $20-50 \%$. These very significant alterations are 


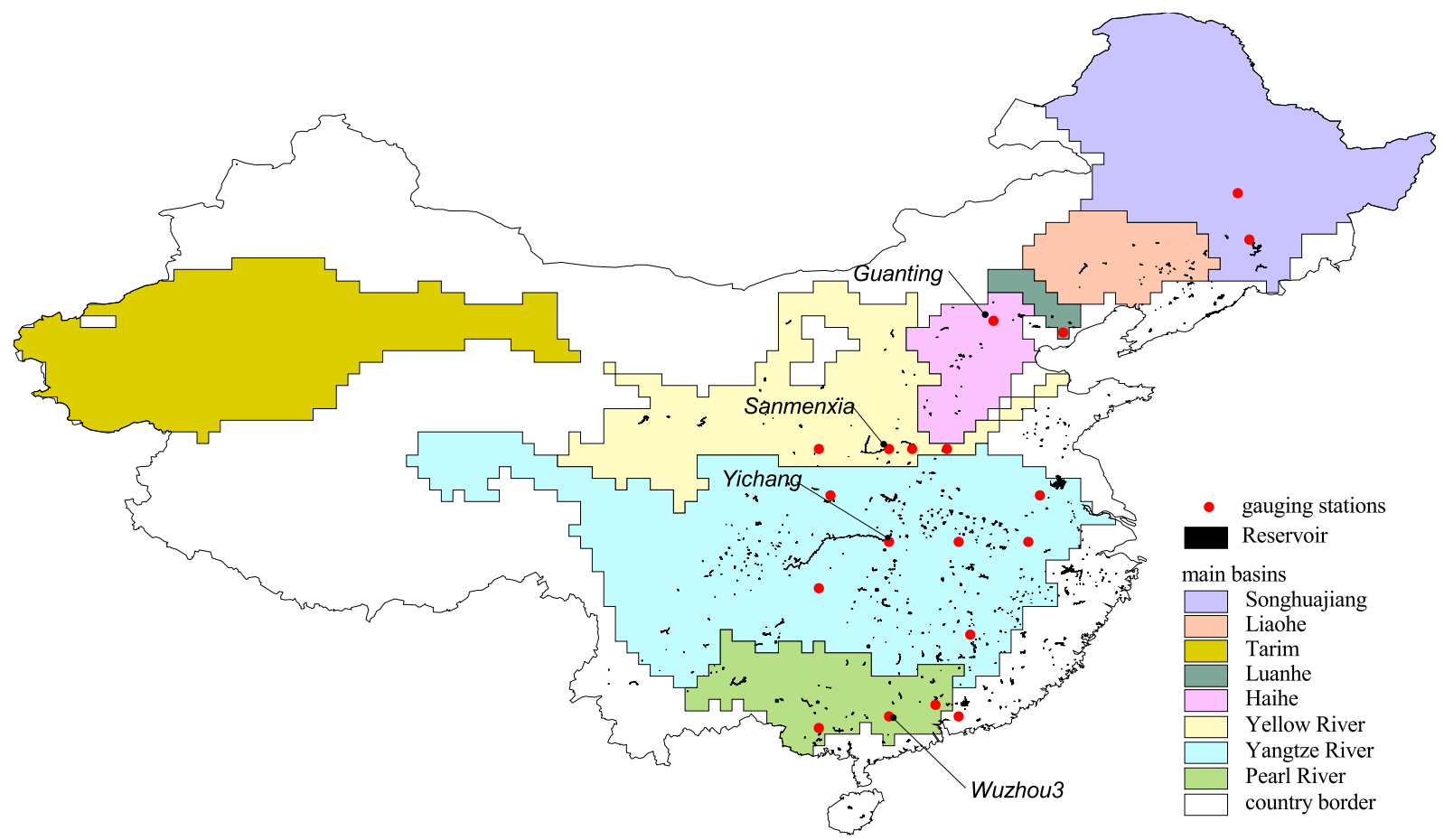

Fig. 2. Map of reservoirs, main river basins and selected gauging stations in China, as included in this study.
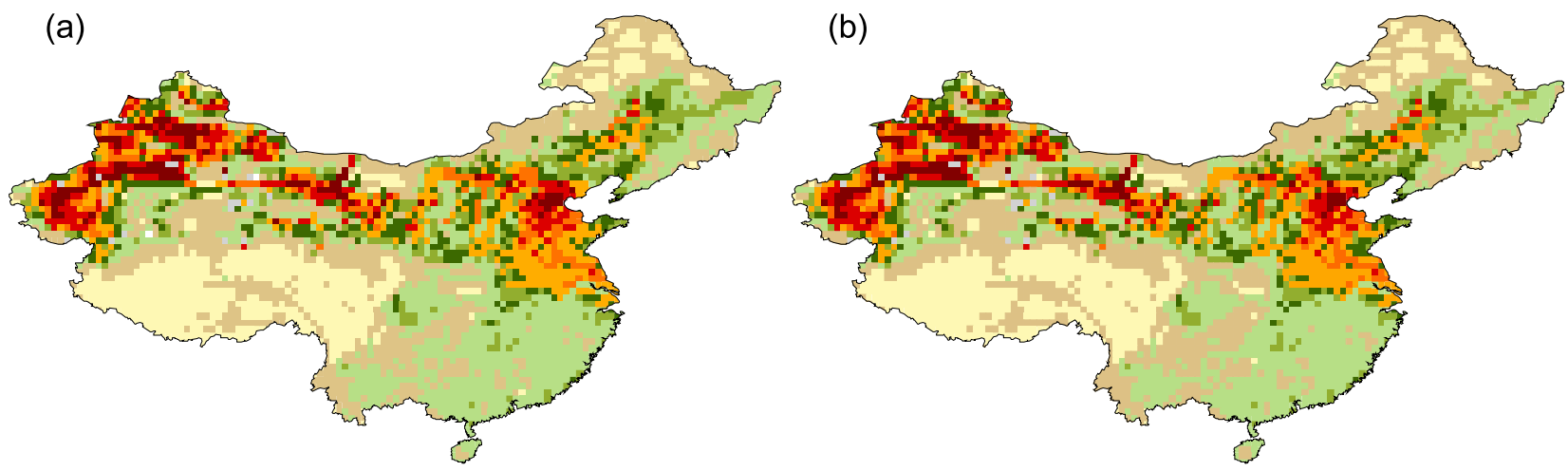

(c)

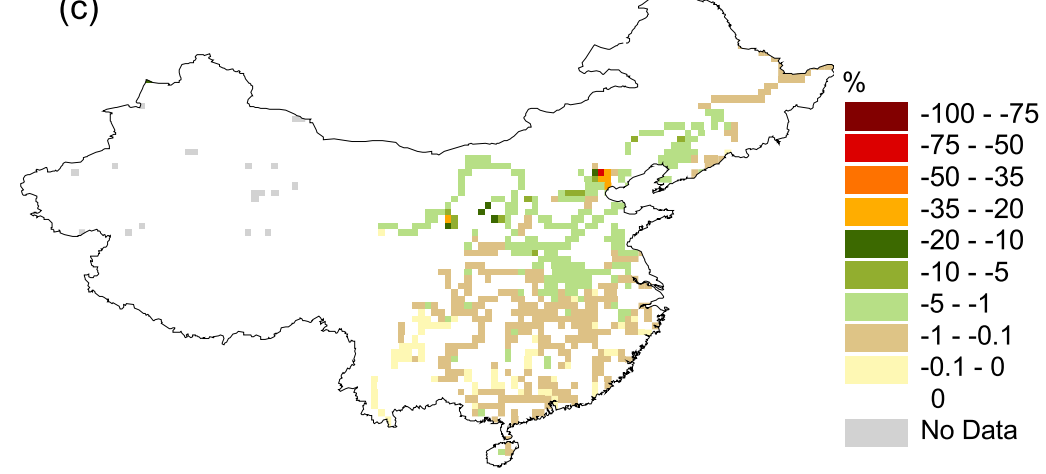

Fig. 3. Alteration of long-term average (1961-1990) annual river discharge under natural flow conditions (NAT) due to human water use and reservoirs (AAF) (a), or only due to human withdrawal water use (USE) (b), or only due to the existence of reservoirs (RES) (c). Data shown are the difference between the anthropogenically altered value and NAT in percent of NAT. 


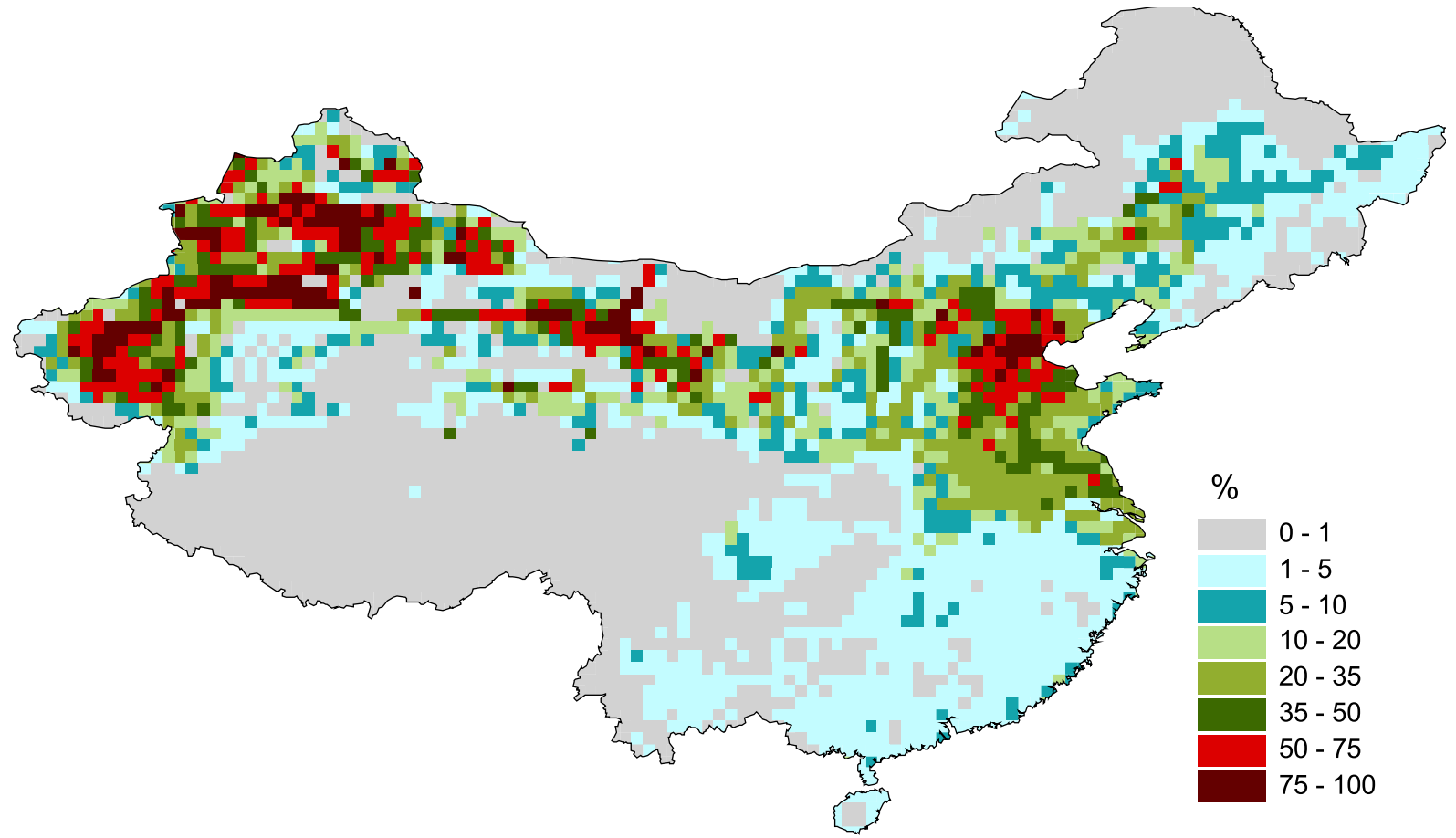

Fig. 4. Average annual water consumption (part of water withdrawal that evapotranspirates during use) of China for the period 1961-1990, calculated by WaterGAP as the difference between AAF and RES, in percent of RES.
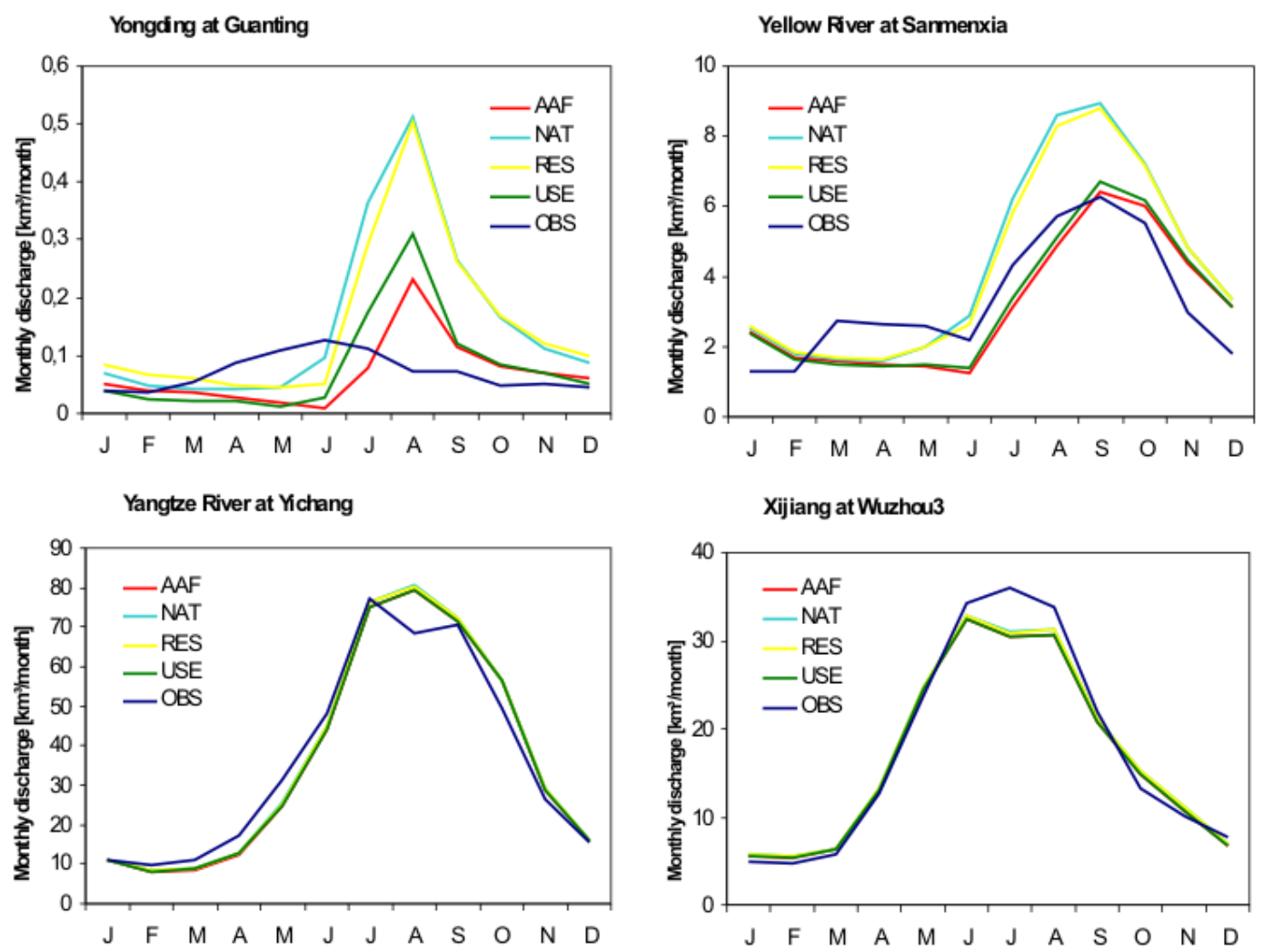

Fig. 5. Modeled and observed long-term mean monthly discharges (1961-1990) at selected gauging stations in China 


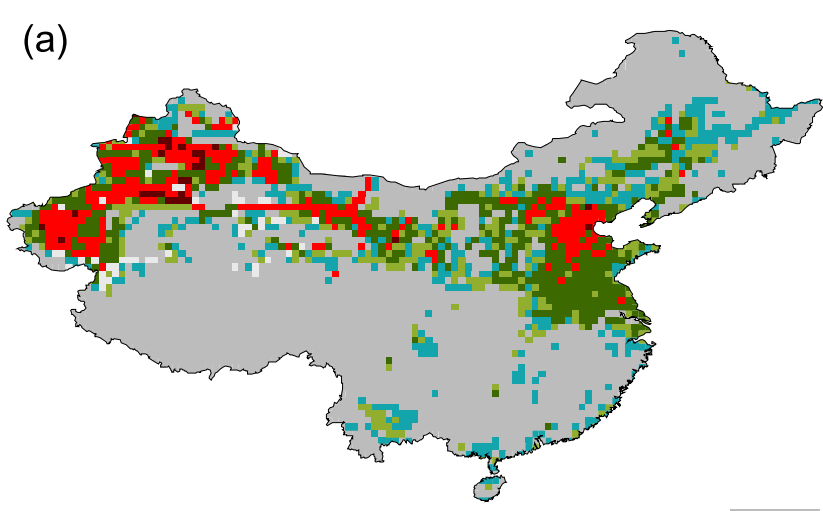

(b)
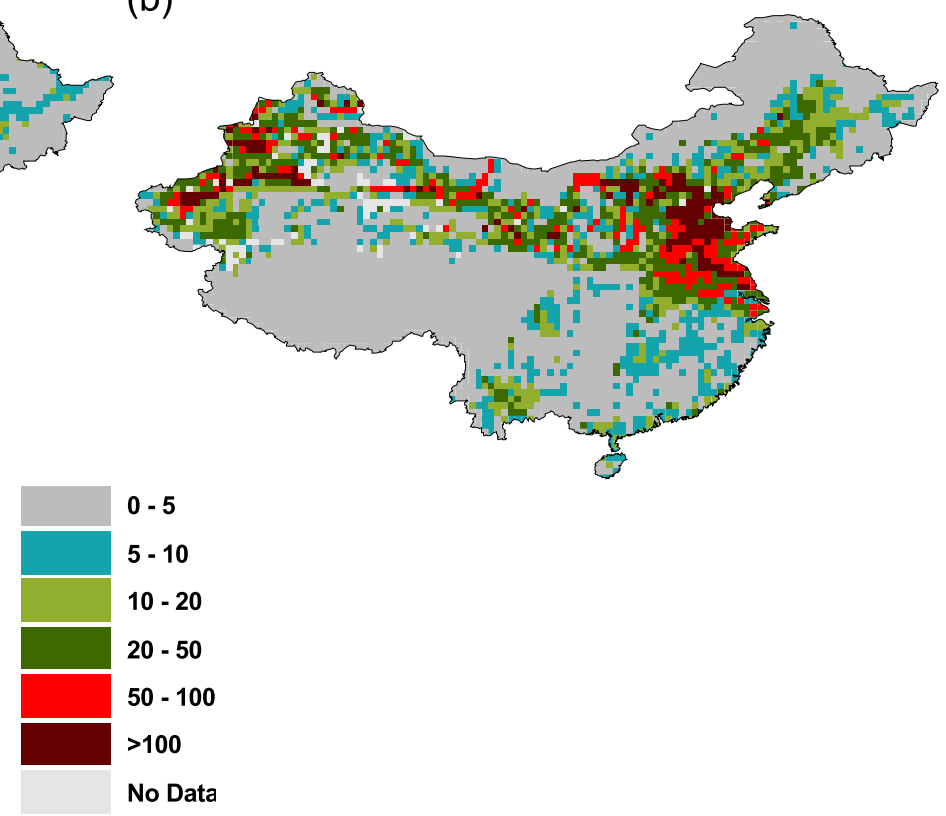

$0-5$

$5-10$

$10-20$

$20-50$

- 100

No Data

Fig. 6. Average absolute change in monthly mean river discharge (a) and coefficients of variation of monthly mean discharge (b) between natural (NAT) and anthropogenically altered (AAF) conditions (1961-1990), in \%.

contrasted by the only small reductions of less than $5 \%$, in the northern Songhuajiang basin and in the southern half of China, including most of the Yangtze River basin, the Pearl River basin and the southern parts of western China. The difference between USE and NAT (see Fig. 3b) are very similar to the differences between AAF and NAT. The comparison of RES and NAT (see Fig. 3c) shows significant differences only in the Haihe River basin and in the Yellow River basin. This means that reservoir evaporation has a much smaller impact on long-term average river discharges and thus total renewable water resources than human water use. Irrigation water use is significantly higher in the north of China than in the south, and dominates total water consumption (part of the withdrawn water that evapotranspirates during use) that is depicted in Fig. 4.

In Fig. 5, modeled long-term mean monthly discharges (1961-1990) under the four flow conditions as well as observed data at four selected gauging stations in China are compared. The values of NAT (and RES) show much larger amplitudes than AAF and the observed data for the Yongding River (a tributary of Haihe River) at Guanting and the Yellow River at Sanmenxia. The differences between AAF and the measured data at these two stations are likely to be partly due to the fact that reservoir management is not correctly represented in WaterGAP. In WaterGAP, reservoirs are currently assumed to behave like natural lakes. For the Yangtze River at Yichang and the Xijiang (a tributary of Pearl River) at Wuzhou3, the patterns of all simulated and observed flows look very similar, as river discharge is large in these basins compared to water consumption and reservoir capacity.

The comparison of average absolute changes in monthly means and coefficients of variation between natural and anthropogenically altered condition in Fig. 6 shows spatial patterns that are quite similar to the patterns of change in the long-term average river discharge. Where long-term average river discharge is reduced significantly by water consumption, the mean monthly values are reduced, too, and $M N_{\text {diff }}$ does not provide obvious additional information (Fig. 6a). Please note, however, that the impact of reservoirs on monthly discharges is underestimated by the model as WaterGAP treats reservoirs as lakes, and thus the actual alterations of the flow regime should be underestimated by the model. $C V_{\text {diff }}$ (Fig. 6b) reflects the degree to which the inter-annual variability of monthly flow has been changed by water consumption and reservoirs. It is somewhat larger that $M N_{\text {diff }}$ in the Haihe and the northeastern part of Yangtze River basin, and somewhat lower in the north-western part of China.

\section{Conclusions}

A first assessment of human-induced alterations in river flow regimes in China has been achieved based on the comparison of calculated long-term river discharge (1961-1990) under natural and anthropogenically altered conditions (impact of human water consumption and reservoirs). The results show very significant alterations of natural river flow regimes in 
large part of northern China and only minor alterations in most of southern China. The alterations refer to the longterm average river discharge, i.e. the renewable water resources, the seasonality of flows and the inter-annual variability. All these types of alteration are known to have an impact on the ecosystems. Human water consumption, mainly for irrigation, has been shown to be the dominating cause of the alterations, while the influences of reservoirs appear to be small. With respect to seasonality and possibly interannual variability, however, WaterGAP is very likely to underestimate the impact of reservoirs.

For an improved assessment of human impacts on stream flow variability, it is necessary to model reservoir dynamics more realistically. Therefore, a new reservoir algorism which takes into account the dynamics of storage capacity will be integrated into WaterGAP model. In a further step, a more detailed analysis of ecologically relevant hydrological changes in selected basins in China will be done, which includes consideration of impacts on specific aquatic species and of local knowledge on habitat degradation.

Edited by: F. Portmann, K. Berkhoff, and M. Hunger

Reviewed by: four anonymous referees and the editors

\section{References}

Alcamo, J., Döll, P., Henrichs, T., Kaspar, F., Lehner, B., Rösch, T., and Siebert, S.: Development and testing of the WaterGAP 2 global model of water use and availability, Hydrol. Sci. J., 48(3), 317-338, 2003.

Arthington, A. H. and Pusey, B. J.: In-stream flow management in Australia: methods, deficiencies and future directions, Australian Biology, 6, 52-60, 1993.
Black, A. R., Rowan, J. S., Duck, R. W., Bragg, O. M., and Clelland, B. E.: DHRAM: a method for classifying river flow regime alterations for the EC Water Framework Directive, Aquatic Conservation: Marine and freshwater Ecosystems, 15, 427-446, 2005.

Clausen, B. and Biggs, B. J. F.: Flow variables for ecological studies in temperate streams: groupings based on covariance, J. Hydrol., 237, 184-197, 2000.

Döll, P., Kaspar, F., and Lehner, B.: A global hydrological model for deriving water availability indicators: model tuning and validation, J. Hydrol., 270(1-2), 105-134, 2003.

Government of China: White Paper on China's Strategy for Population, Environment and Development in the 21 st Century, chapter 14, http://www.acca21.org.cn/ca21pa.html, 1994.

Hunger, M. and Döll, P.: Value of river discharge data for globalscale hydrological modeling, Hydrol. Earth Syst. Sci. Discuss., 4, 4125-4173, 2007, http://www.hydrol-earth-syst-sci-discuss.net/4/4125/2007/.

Lehner, B. and Döll, P.: Development and validation of a global database of lakes, reservoir and wetlands, J. Hydrol., 296(1-4), 1-22, 2004.

Poff, N. L., Allan, D. J., Brain, M. B., Karr, J. R., Prestegaard, K. L., Richter, B. D., Sparks, R. E., and Stromberg, J. C.: The natural flow regime: a paradigm for river conservation and restoration. BioScience, 47(11), 769-784, 1997.

Poff, N. L. and Ward, J. V.: Implications of stream flow variability and predictability for lotic community structure: a regional analysis of stream flow patterns, Can. J. Fish. Aquat. Sci., 46, 1805-1818, 1989.

Puckridge, J. T., Sheldon, F., Walker, K. F., and Boulton, A. J.: Flow variability and the ecology of large rivers. Mar. Freshwater Res., 49, 55-72, 1998.

Richter, B. D., Baumgartner, J. V., Powell, J., and Braun, D. P.: A method for assessing hydrologic alteration within ecosystems, Conservation Biology, 10(4), 1163-1174, 1996.

Richter, B. D., Baumgartner, J. V. Wigington, R., and Braun, D. P.: How much water does a river need?, Freshwater Biology, 37, 231-249, 1997. 